FACTA UNIVERSITATIS

Series: Physical Education and Sport, Vol. 18, No 3, 2020, pp. 559 - 566

https://doi.org/10.22190/FUPES200615054L

Research article

\title{
RELIABILITY OF TESTS FOR SPEED AND AGILITY ASSESSMENT IN CADET BASKETBALL PLAYERS
}

\author{
UDC 796.012: 323.2
}

\section{Miloš Lukić, Adam Petrović, Nemanja Ćopić, Svetlana Petronijević, Srećko Jovanović}

\author{
Faculty of Sport, University "Union-Nikola Tesla”, Belgrade, Serbia
}

\begin{abstract}
The aim of this research is to determine whether the Illinois test (IL), T-test (Tt), $4 x 5 \mathrm{~m}$ Shuttle run (4x5m), $20 \mathrm{~m}$ Sprint ( $\mathrm{S} 20 \mathrm{~m}$ ), $10 \mathrm{~m}$ Sprint ( $\mathrm{S10m}$ ) are reliable tests in assessing the speed and agility of cadet basketball players. The strategy of this research involved a traditional quantitative approach to research with a correlation studies design. The total sample consisted of 38 male participants. The mean age of the participants was $-A G E=16.03$ years, body height $-B H=183.5 \mathrm{~cm}$; body mass-BM=74.1 $\mathrm{kg}$; Body Mass Index-BMI $=22.08 \mathrm{~kg} / \mathrm{m}^{2}$. The most reliable agility test when performing without a ball is IL $L_{N B}$, while less reliable are $T t_{N B}$ and the $4 x 5 m_{N B}$, both without a ball. A reliable test that is performed without a ball to assess the speed of a cadet basketball player is the S1Om $\mathrm{m}_{N B}$. On the other hand, all speed and agility tests when performed with a ball are reliable for testing cadet basketball players. The proposed speed and agility tests have proven to be reliable for cadet basketball players.
\end{abstract}

Key words: Illinois test, T-test, $4 \times 5$ m Shuttle Run, Sprint

\section{INTRODUCTION}

There are many theories of motor abilities in which speed, as well as its structural elements, plays a part (Kukolj, 2006; Petrović, 2014; Nikolić, Berić, Kocić, Daskalovski, 2017). The concept of maximum human speed contains maximum speed of human motion: a) in the shortest time interval; b) at a minimum external load (minimal exertion of muscle force); and c) in the conditions of minimal requests from the aspect of complexity i.e., coordination (Petrović, 2014).

There are many definitions of agility, and one of them indicates that agility is the fastest possible movement in a curvilinear path (Petrović, 2014). In many studies agility is any

Received June 15, 2020/ Accepted December 08, 2020

Corresponding author: Nemana Ćopić

Faculty of Sport, University "Union-Nikola Tesla”, Narodnih heroja 30/I, 11070 Novi Beograd, Serbia

Phone: + 381114044050 •E-mail: nemanjacopic@yahoo.com

ㄷ 2020 by University of Niš, Serbia | Creative Commons License: CC BY-NC-ND 
dynamic movement that involves a change in body position (Draper \& Lancaster, 1985; Fulton, 1992; Hastad \& Lacy, 1994; Sheppard \& Young, 2006). Agility represents a concept derived from force-velocity, velocity-time and velocity-complexity relations (Petrović, 2014).

Sheppard and Young (2006) define agility as whole-body movements with changes in speed and direction that are performed in response to a particular impulse. There are two basic factors that define agility: perceptual and decision-making factors and change in direction of speed, as well as multiple sub-factors (Young, James, \& Montgomery, 2002; Young \& Farrow, 2006). It should be added that running technique has an important role in performed tests with a change of direction and speed (Sayers, 2000; Bompa \& Haff, 2009). Agility is often divided to predetermined changes in direction of speed and where the direction of movement is performed in response to a given impulse (Scanlan et al., 2016).

There are widespread testings of speed and agility in various sports (Little \& Williams, 2003; Leone, Comtois, Tremblay, \& Léger, 2006; Gabbett, Kelly, \& Sheppard, 2008; Spasić, Krolo, Zenić, Delextrat, \& Sekulić, 2015). Generally, speed and agility tests can be the Illinois test, T-test, 4x5 m Shuttle run, Zig-Zag, $20 \mathrm{~m}$ or $10 \mathrm{~m}$ Sprint, while specific speed and agility tests are modifications of general tests or specially designed tests to assess the specific abilities of athletes in various sports disciplines.

Speed and agility have been the subject of a lot of research in basketball (Jakovljević, Karalejić, Pajić, Macura, \& Erculj, 2012; Delextrat, Grosgeorge, \& Bieuzen, 2015; Gil et al., 2015; Yanci et al., 2015), but it remains unknown whether the previously mentioned tests are reliable for testing cadet basketball players.

The aim of this research is to determine whether the Illinois test, T-test, $4 \times 5 \mathrm{~m}$ Shuttle run, $10 \mathrm{~m}$ Sprint, $20 \mathrm{~m}$ Sprint are reliable tests in assessing the speed and agility of cadet basketball players.

\section{METHODS}

\section{Research Design}

The strategy of this research involved a traditional quantitative approach to research with a correlation studies design. The correlation was calculated between the test and retest, as well as between separate tests performed with and without a ball.

\section{Sample}

The total sample size was 38 male participants. The first testing (Test), conducted in the first week, included 38 participants, while the second testing (Retest), conducted seven days later, included 33 participants. In both tests the same participants were tested. The sample dropout rate is 5 participants. The average age of the participants was Age $=16.03 \pm 0.49 \mathrm{yrs}$, body height $-\mathrm{BH}=183.5 \pm 6.15 \mathrm{~cm}$, body mass - $\mathrm{BM}=74.1 \pm 9.93 \mathrm{~kg}$; Body Mass Index $\mathrm{BMI}=22.08 \pm 2.16 \mathrm{~kg} / \mathrm{m}^{2}$ (Mean $\left.\pm \mathrm{SD}\right)$. All of the participants have practiced basketball for an average of 2 years and 6 months, 5-7 times a week. The participants are members of two basketball clubs, competing in a league organized by the Basketball Federation of Serbia on the territory of the City of Belgrade. The study was conducted in accordance with the tenets of the Declaration of Helsinki. 


\section{Testing procedures}

In this study two basic variables were examined - the speed and agility of cadet basketball players. Speed was tested in 4 tests, while agility was tested in 6 tests. The order of the tests was as follows:

The set of tests to estimate speed:

1. S20 $\mathrm{m}_{\mathrm{NB}}-20 \mathrm{~m}$ Sprint without a ball; 2. S20m $-20 \mathrm{~m}$ Sprint with a ball; 3. S10m $\mathrm{m}_{\mathrm{NB}}-$ $10 \mathrm{~m}$ Sprint without a ball; 4. S10 $\mathrm{m}_{\mathrm{B}}-10 \mathrm{~m}$ Sprint with a ball.

The set of tests to estimate agility:

1. $\mathrm{IL}_{\mathrm{NB}}$ - Illinois test without a ball; 2. $\mathrm{IL}_{\mathrm{B}}$ - Illinois test with a ball; 3. $\mathrm{Tt}_{\mathrm{NB}}-\mathrm{T}$-test without a ball; 4 . $\mathrm{Tt}_{\mathrm{B}}-\mathrm{T}$-test with a ball; $5.4 \times 5 \mathrm{~m}_{\mathrm{NB}}-4 \times 5 \mathrm{~m}$ Shuttle run without a ball; 6 . $4 \times 5 m_{B}-4 \times 5 m$ Shuttle run with a ball.

Each participant had two attempts per test. The better result was taken for data analysis. The tests were conducted one after the other. Before each test, the participants were given clear instructions on how to perform the test. The space was specifically adapted for this type of testing. Time was measured for the same person in the test and retest. After warming up the participants performed the tests. Between each test there was a break of 3 minutes. The order of participants during the testing was the same in the test and retest. The measurement equipment used in this research was: a Beurer PS 240 digital scale, body height meter, Rucanor stopwatch 12, cones, and aMolten dolphin whistle.

\section{Statistical analysis}

In this study, the basic descriptive statistics (Mean, SD, Min, Max) for all the studied variables were calculated. The Pearson correlation coefficient (r) was calculated in order to show the relationship between the measured variables in Test-Retest. Also, Pearson's correlation coefficient was calculated to indicate the relationship between tests performed without a ball and tests performed with a ball. The threshold of statistically significant statistical difference stood at a $95 \%$ probability level, $\mathrm{p}=0.05$. All statistical procedures were carried out by the Microsoft ${ }^{\circledR}$ Office Excel 2007 and the SPSS for Windows, Release 17.0 (Copyright @ SPSS Inc., 1989-2002)

\section{RESULTS}

Table 1 shows the basic descriptive statistics, mean (M), standard deviation (SD), minimum (min) and maximum (max) values, as well as the difference in mean values (difference, $\mathrm{s}$ ) in the Test and Retest. Also, the studied variables of the reliability of the tests are shown.

Table 2 shows the relationship between the results obtained in the Test-Retest. This relationship was investigated using the Pearson correlation coefficient. A strong correlation was calculated within all the variables in the Test-Retest, except for the S20 $\mathrm{m}_{\mathrm{NB}}$ test.

A strong correlation was found between the following tests: $\mathrm{IL}_{\mathrm{NB}} \& \mathrm{RE} \_\mathrm{IL} \mathrm{NB}, \mathrm{r}=0.859$, $\mathrm{p}<0.01 ; \mathrm{IL}_{\mathrm{B}} \& \mathrm{RE} \_\mathrm{IL}_{\mathrm{B}}, \mathrm{r}=0.838, \mathrm{p}<0.01 ; \mathrm{Tt}_{\mathrm{NB}} \& \mathrm{RE} \_\mathrm{Tt}_{\mathrm{NB}}, \mathrm{r}=0.883, \mathrm{p}<0.01 ; \mathrm{T}_{\mathrm{B}} \& \mathrm{RE} \_\mathrm{T}_{\mathrm{B}}$, $\mathrm{r}=0.817, \mathrm{p}<0.01 ; 4 \times 5 \mathrm{~m}_{\mathrm{NB}} \&$ RE_4x $5 \mathrm{~m}_{\mathrm{NB}}, \mathrm{r}=0.853, \mathrm{p}<0.01 ; 4 \times 5 \mathrm{~m}_{\mathrm{B}} \&$ RE_4x $5 \mathrm{~m}_{\mathrm{B}}, \mathrm{r}=0.871$, $\mathrm{p}<0.01$.

A lower correlation was found between the following tests: $\mathrm{S} 10 \mathrm{~m}_{\mathrm{B}}$ \& RE_S10m $\mathrm{B}$, $\mathrm{r}=0.737, \mathrm{p}<0.01 ; \mathrm{S} 20 \mathrm{~m}_{\mathrm{B}} \&$ RE_S $20 \mathrm{~m}_{\mathrm{B}}, \mathrm{r}=0.617, \mathrm{p}<0.01 ; \mathrm{S} 10 \mathrm{~m}_{\mathrm{NB}} \&$ RE_S $10 \mathrm{~m}_{\mathrm{NB}}$, $\mathrm{r}=0.576, \mathrm{p}<0.01$, and no statistically significant correlation was found between the Test Retest in maximum speed testing at $20 \mathrm{~m}$ without a ball $\mathrm{S} 20 \mathrm{~m}_{\mathrm{NB}}, \mathrm{r}=0.245, \mathrm{p}>0.05$. 
Table 1 Descriptive indicators of tested variables

\begin{tabular}{|c|c|c|c|c|c|c|c|}
\hline Variables & Tests & Measurement & Mean \pm SD (s) & $\% \mathrm{cV}$ & Min & $\overline{M a x}$ & Difference (s) \\
\hline \multirow{8}{*}{ 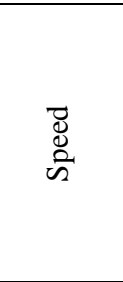 } & \multirow[b]{2}{*}{$\mathrm{S} 20 \mathrm{~m}_{\mathrm{NB}}$} & Test & $3.37 \pm 0.24$ & 7.12 & 2.79 & 3.89 & \multirow[b]{2}{*}{0.03} \\
\hline & & Retest & $3.34 \pm 0.29$ & 8.68 & 2.25 & 3.89 & \\
\hline & \multirow{2}{*}{$\mathrm{S} 20 \mathrm{~m}_{\mathrm{B}}$} & Test & $3.54 \pm 0.26$ & 7.34 & 3.04 & 4.14 & \multirow{2}{*}{0.07} \\
\hline & & Retest & $3.47 \pm 0.26$ & 7.49 & 2.95 & 3.95 & \\
\hline & \multirow{2}{*}{$\mathrm{S} 10 \mathrm{mnB}$} & Test & $2.05 \pm 0.20$ & 9.76 & 1.67 & 2.5 & \multirow{2}{*}{0.05} \\
\hline & & Retest & $2.00 \pm 0.18$ & 9.00 & 1.72 & 2.36 & \\
\hline & \multirow{2}{*}{$\mathrm{S} 10 \mathrm{~m}_{\mathrm{B}}$} & Test & $2.13 \pm 0.18$ & 8.45 & 1.79 & 2.54 & \multirow{2}{*}{0.08} \\
\hline & & Retest & $2.05 \pm 0.18$ & 8.78 & 1.72 & 2.37 & \\
\hline \multirow{12}{*}{ 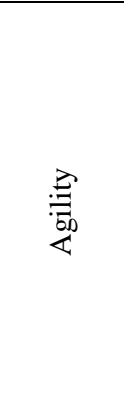 } & \multirow{2}{*}{$\mathrm{IL}_{\mathrm{NB}}$} & Test & $16.07 \pm 0.60$ & 3.73 & 15.05 & 17.38 & \multirow{2}{*}{0.00} \\
\hline & & Retest & $16.07 \pm 0.68$ & 4.23 & 14.93 & 17.45 & \\
\hline & \multirow{2}{*}{$\mathrm{IL}_{\mathrm{B}}$} & Test & $16.82 \pm 0.83$ & 4.93 & 15.57 & 18.53 & \multirow{2}{*}{0.44} \\
\hline & & Retest & $16.38 \pm 0.74$ & 4.52 & 14.91 & 18.03 & \\
\hline & \multirow{2}{*}{$\mathrm{Tt}_{\mathrm{NB}}$} & Test & $10.82 \pm 0.60$ & 5.55 & 9.42 & 12.17 & \multirow{2}{*}{0.17} \\
\hline & & Retest & $10.64 \pm 0.61$ & 5.73 & 9.11 & 11.97 & \\
\hline & \multirow{2}{*}{$\mathrm{Tt}_{\mathrm{B}}$} & Test & $11.42 \pm 0.64$ & 5.60 & 10.07 & 12.3 & \multirow{2}{*}{0.28} \\
\hline & & Retest & $11.14 \pm 0.61$ & 5.48 & 9.69 & 12.16 & \\
\hline & \multirow{2}{*}{$4 \times 5 \mathrm{mnB}$} & Test & $6.77 \pm 0.46$ & 6.79 & 5.91 & 7.57 & \multirow{2}{*}{0.01} \\
\hline & & Retest & $6.76 \pm 0.65$ & 9.62 & 5.64 & 8.16 & \\
\hline & \multirow{2}{*}{$4 \times 5 m_{B}$} & Test & $6.99 \pm 0.61$ & 8.73 & 5.96 & 8.05 & \multirow{2}{*}{0.02} \\
\hline & & Retest & $6.97 \pm 0.79$ & 11.33 & 5.70 & 8.67 & \\
\hline
\end{tabular}

Legend: S20m $\mathrm{m}_{\mathrm{NB}}-20 \mathrm{~m}$ Sprint without a ball; S20m $\mathrm{m}_{\mathrm{B}}-20 \mathrm{~m}$ Sprint with a ball; S10m $\mathrm{m}_{\mathrm{NB}}-10 \mathrm{~m}$ Sprint without a ball $\mathrm{S} 10 \mathrm{~m}_{\mathrm{B}}-10 \mathrm{~m}$ Sprint with a ball; $\mathrm{IL}_{\mathrm{NB}}$-Illinois test without a ball; $\mathrm{IL}_{\mathrm{B}}$-Illinois test with a ball; $\mathrm{Tt}_{\mathrm{NB}}-\mathrm{T}$-test without a ball, $\mathrm{Tt}_{\mathrm{B}}$-T-test with a ball; $4 \times 5 \mathrm{~m}_{\mathrm{NB}}-4 \times 5 \mathrm{~m}$ Shuttle run without a ball, $4 \times 5 \mathrm{~m}_{\mathrm{B}}-4 \times 5 \mathrm{~m}$ Shuttle run with a ball; RE-Retest; r-Pearson correlation coefficient; Sig.-statistical significance *p<0.05, $* * p<0.01$

Table 2 Basic statistics of correlation analysis in Test-Retest

\begin{tabular}{|c|c|c|c|c|c|c|c|c|c|c|c|}
\hline Test/Retest & Corr. & $\begin{array}{c}\text { RE_S20 } \\
\mathrm{m}_{\mathrm{NB}}\end{array}$ & $\begin{array}{c}\text { RE_S20 } \\
\mathrm{m}_{\mathrm{B}}\end{array}$ & $\begin{array}{c}\text { RE_S10 } \\
\mathrm{m}_{\mathrm{NB}}\end{array}$ & $\begin{array}{c}\text { RE_S10 } \\
\mathrm{m}_{\mathrm{B}}\end{array}$ & RE_IL ${ }_{N B}$ & RE_IL ${ }_{B}$ & $\underset{B}{R E \_t_{N}}$ & $\begin{array}{c}\text { RE_Tt } \\
\text { B }\end{array}$ & $\begin{array}{c}\text { RE_4x } 5 m_{N} \\
B\end{array}$ & $\begin{array}{c}\text { RE_4x5m } \\
\text { B }\end{array}$ \\
\hline \multirow[t]{2}{*}{$\mathrm{S} 20 \mathrm{~m}_{\mathrm{NB}}$} & $r$ & 0.245 & $0.431^{*}$ & $0.430^{*}$ & $.455^{* * 1 *}$ & $0.374^{*}$ & $0.525^{* * *}$ & $0.544^{* * *}$ & $0.664^{* *}$ & $0.501^{* *}$ & $0.459^{* * *}$ \\
\hline & Sig. & 0.170 & 0.012 & 0.013 & 0.008 & 0.032 & 0.002 & 0.001 & 0.000 & 0.003 & 0.007 \\
\hline \multirow[t]{2}{*}{$\mathrm{S} 20 \mathrm{~m}_{\mathrm{B}}$} & $r$ & & $0.617^{* *}$ & 0.276 & $0.567^{* *}$ & $0.396^{*}$ & $0.346^{*}$ & $0.452^{* *}$ & $0.497^{* *}$ & 0.255 & 0.271 \\
\hline & Sig. & & 0.000 & 0.120 & 0.001 & 0.022 & 0.049 & 0.008 & 0.003 & 0.152 & 0.127 \\
\hline \multirow[t]{2}{*}{$\mathrm{S} 10 \mathrm{~m}_{\mathrm{NB}}$} & $r$ & & & $0.576^{* *}$ & $0.651^{* *}$ & 0.131 & 0.102 & $0.598^{* *}$ & $0.647^{* *}$ & $0.593^{* *}$ & $0.615^{* *}$ \\
\hline & Sig. & & & 0.000 & 0.000 & 0.469 & 0.574 & 0.000 & 0.000 & 0.000 & 0.000 \\
\hline \multirow[t]{2}{*}{$\mathrm{S} 10 \mathrm{~m}_{\mathrm{B}}$} & $r$ & & & & $0.737^{* *}$ & 0.172 & 0.163 & $0.500^{* *}$ & $0.600^{* *}$ & $0.530^{* *}$ & $0.581^{\text {** }}$ \\
\hline & Sig. & & & & 0.000 & 0.337 & 0.366 & 0.003 & 0.000 & 0.001 & 0.000 \\
\hline \multirow[t]{2}{*}{$\mathrm{IL}_{\mathrm{NB}}$} & $r$ & & & & & $0.895^{* *}$ & $0.800^{* * *}$ & $0.397^{*}$ & 0.344 & -0.035 & -0.135 \\
\hline & Sig. & & & & & 0.000 & 0.000 & 0.022 & 0.050 & 0.847 & 0.455 \\
\hline \multirow{2}{*}{$\mathrm{IL}_{\mathrm{B}}$} & $r$ & & & & & & $0^{0.838}{ }^{* * *}$ & 0.284 & 0.340 & -0.047 & -0.100 \\
\hline & Sig. & & & & & & 0.000 & 0.110 & 0.053 & 0.795 & 0.580 \\
\hline \multirow{2}{*}{$\mathrm{Tt}_{\mathrm{NB}}$} & $r$ & & & & & & & $0.883^{* *}$ & $0.796^{* *}$ & $0.484^{* *}$ & $0.430^{*}$ \\
\hline & Sig. & & & & & & & 0.000 & 0.000 & 0.004 & 0.013 \\
\hline \multirow{2}{*}{$\mathrm{Tt}_{\mathrm{B}}$} & $r$ & & & & & & & & $0.817^{* *}$ & $0.689^{* *}$ & $0.633^{* *}$ \\
\hline & Sig. & & & & & & & & 0.000 & 0.000 & 0.000 \\
\hline \multirow{2}{*}{$4 \mathrm{x} 5 \mathrm{~m}_{\mathrm{NB}}$} & $r$ & & & & & & & & & $0.853^{* *}$ & $0.813^{* *}$ \\
\hline & Sig. & & & & & & & & & 0.000 & 0.000 \\
\hline \multirow{2}{*}{$4 \times 5 m_{B}$} & $r$ & & & & & & & & & & $0.871^{* * *}$ \\
\hline & Sig. & & & & & & & & & & 0.000 \\
\hline
\end{tabular}

Legend: $\mathrm{S} 20 \mathrm{~m}_{\mathrm{NB}}-20 \mathrm{~m}$ Sprint without a ball; $\mathrm{S} 20 \mathrm{~m}_{\mathrm{B}}-20 \mathrm{~m}$ Sprint with a ball; $\mathrm{S} 10 \mathrm{~m}_{\mathrm{NB}}-10 \mathrm{~m}$ Sprint without a ball; $\mathrm{S} 10 \mathrm{~m}_{\mathrm{B}}-10 \mathrm{~m}$ Sprint with a ball; $\mathrm{IL}_{\mathrm{NB}}$-Illinois test without a ball; $\mathrm{IL}_{\mathrm{B}}$-Illinois test with a ball; $\mathrm{Tt}_{\mathrm{NB}}$-T-test without a ball; $\mathrm{Tt}_{\mathrm{B}}$-T-test with a ball; $4 \times 5 \mathrm{~m}_{\mathrm{NB}}-4 \times 5 \mathrm{~m}$ Shuttle run without a ball; $4 \times 5 \mathrm{~m}_{\mathrm{B}}-4 \times 5 \mathrm{~m}$ Shuttle run with a ball; RE-Retest, r-Pearson correlation coefficient; Sig.-statistical significance $* \mathrm{p}<0.05, * *_{\mathrm{p}}<0.01$ 
Table 3 shows the relationship between the results obtained in tests performed without a ball and with a ball. This relationship is expressed by the Pearson correlation coefficient. The calculated correlation showed statistical significance between all the tests.

Table 3 Correlation analysis between tests performed with and without a ball

\begin{tabular}{|c|c|c|c|c|c|c|}
\hline Tests & Corr. & $\mathrm{S} 20 \mathrm{~m}_{\mathrm{B}}$ & $\mathrm{S} 10 \mathrm{~m}_{\mathrm{B}}$ & $\mathrm{IL}_{\mathrm{B}}$ & $\mathrm{Tt}_{\mathrm{B}}$ & $4 \times 5 m_{B}$ \\
\hline \multirow{2}{*}{$\mathrm{S} 20 \mathrm{~m}_{\mathrm{NB}}$} & $r$ & $0.421^{* * *}$ & $0.457^{* *}$ & $0.347^{*}$ & $0.546^{* *}$ & $0.602^{* * *}$ \\
\hline & Sig. & 0.008 & 0.004 & 0.033 & 0.000 & 0.000 \\
\hline \multirow{2}{*}{$\mathrm{S} 10 \mathrm{~m} \mathrm{NB}$} & $r$ & & $0.739^{* *}$ & -0.119 & $0.490^{* * *}$ & $0.633^{* * *}$ \\
\hline & Sig. & & 0.000 & 0.475 & 0.002 & 0.000 \\
\hline \multirow{2}{*}{ IL $_{\mathrm{NB}}$} & $r$ & & & $0.814^{* * *}$ & $0.479^{* *}$ & -0.035 \\
\hline & Sig. & & & 0.000 & 0.002 & 0.833 \\
\hline \multirow{2}{*}{$\mathrm{Tt}_{\mathrm{NB}}$} & $r$ & & & & 0.726 *** & $0.456^{\text {** }}$ \\
\hline & Sig. & & & & 0.000 & 0.004 \\
\hline \multirow{2}{*}{$4 \times 5 m_{N B}$} & $r$ & & & & & $0.847^{* * *}$ \\
\hline & Sig. & & & & & 0.000 \\
\hline
\end{tabular}

Legend: $\mathrm{S} 20 \mathrm{~m}_{\mathrm{NB}}-20 \mathrm{~m}$ Sprint without a ball; $\mathrm{S} 20 \mathrm{~m}_{\mathrm{B}}-20 \mathrm{~m}$ Sprint with a ball; $\mathrm{S} 10 \mathrm{~m}_{\mathrm{NB}}-10 \mathrm{~m}$ Sprint without a ball; $\mathrm{S} 10 \mathrm{~m}_{\mathrm{B}}-10 \mathrm{~m}$ Sprint with a ball; $\mathrm{IL}_{\mathrm{NB}}$-Illinois test without a ball; $\mathrm{IL}_{\mathrm{B}}$-Illinois test with a ball; $\mathrm{Tt}_{\mathrm{NB}}$-T-test without a ball; $\mathrm{Tt}_{\mathrm{B}}$-T-test with a ball; $4 \times 5 \mathrm{~m}_{\mathrm{NB}}-4 \times 5 \mathrm{~m}$ Shuttle run without a ball; $4 \times 5 \mathrm{~m}_{\mathrm{B}}-4 \times 5 \mathrm{~m}$ Shuttle run with a ball; r-Pearson correlation coefficient; Sig.-statistical significance *p $<0.05$, ** $\mathrm{p}<0.01$

In agility tests the strongest correlation was calculated between the tests $4 \times 5 \mathrm{~m}_{\mathrm{NB}}$ \& $4 \times 5 m_{B} r=0.847, p<0.01$, a lower correlation was calculated between the tests $I_{N B} \& I_{B}$ $\mathrm{r}=0.814, \mathrm{p}<0.01$, while the lowest correlation was calculated between the $\mathrm{Tt}_{\mathrm{NB}} \& \mathrm{Tt}_{\mathrm{B}}$ $\mathrm{r}=0.726, \mathrm{p}<0.01$. Regarding speed tests, a stronger correlation between $\mathrm{S} 10 \mathrm{~m}_{\mathrm{NB}} \& \mathrm{~S} 10 \mathrm{~m}_{\mathrm{B}}$ $\mathrm{r}=0.739, \mathrm{p}<0.01$ was calculated than between $\mathrm{S} 20 \mathrm{~m}_{\mathrm{NB}} \& \mathrm{~S} 20 \mathrm{~m}_{\mathrm{B}} \mathrm{r}=0.421, \mathrm{p}<0.01$.

\section{DISCUSSION}

The results of this study show that there is a relationship between the Test and Retest, which confirms the reliability of almost all the tests performed without and with a ball to assess the speed and agility of cadet basketball players. Testing has shown that the proposed tests are reliable for testing the speed and agility of cadet basketball players. When comparing the results of the correlation analysis of the proposed tests, one can see a good reliability of the agility tests when performed without a ball. The strongest correlation was found for the tests $\mathrm{IL}_{\mathrm{NB}} \mathrm{r}=0.895, \mathrm{p}<0.001$; a smaller correlation was found for $\mathrm{Tt}_{\mathrm{NB}}$, $r=0.883, p<0.001$, while the smallest correlation was found for $4 \times 5 m_{N B} r=0.853, p<0.001$. There is study on a slightly older sample of basketball players where the reliability of IL $(\mathrm{ICC}=0.94)$ and $\mathrm{Tt}(\mathrm{ICC}=0.98)$ was confirmed (Asadi, 2016). Also, there are studies involving basketball where the S20m test for speed assessment and the T-test for agility assessment were used at ages 12 and 14 (Jakovljević et al., 2012). Such findings in this and other studies allow for the proposed agility tests to be used for the cadet basketball players. When it comes to speed tests, the $\mathrm{S} 10 \mathrm{~m}_{\mathrm{NB}}$ test has been shown to be more reliable than the $\mathrm{S} 20 \mathrm{~m}_{\mathrm{NB}}$ test. The test in which the relationship between the Test and Retest has not been confirmed is $\mathbf{S} 20 \mathrm{~m}_{\mathrm{NB}}$. However, in the study of Asadi (2016) different results were obtained which indicate the reliability of the S20m test (ICC=0.97), and in the study of 
Jakovljević et al. (2012) the S20m test is presented as a test to assess the speed of basketball players aged 12 and 14 years.

Generally, there is consensus that the $\mathrm{S} 10 \mathrm{~m}$ and $\mathrm{S} 20 \mathrm{~m}$ tests assess speed. The same speed assessment tests are used in other sports such as: rugby (Gabbett et al., 2008), soccer (Mendez-Villanueva et al., 2011), golf (Hellström, 2008). Based on the criterion relating to theoretical assumptions about speed, the application of the proposed tests in various training studies and practices, and the results obtained from the sample in this study, the hypothesis was confirmed that the $\mathrm{S} 10 \mathrm{mNB}$ test is reliable for testing the speed of a cadet basketball player.

Also, agility tests such as the IL, Tt and $4 \times 5 \mathrm{~m}$ are widely used in agility testing: basketball players (Asadi, 2016; Borović, Rupčić, Matković, Garafolić, \& Dadić, 2016), soccer players (Milanović, Sporiš, Trajković, James, \& Šamija, 2013) rugby and handball players (Hachana et al., 2013). There is consensus among the authors that the mentioned tests assess agility, and the results obtained in this research confirm the possibility of applying these tests among the cadet basketball players. This confirms the hypothesis that the IL, Tt and 4x5m tests are reliable for assessing the agility of cadet basketball players.

The reliability of all agility tests when performed with a ball has been confirmed. The $4 \times 5 m_{B}$ test has the strongest reliability, while $\mathrm{IL}_{\mathrm{B}}$ and $\mathrm{Tt}_{\mathrm{B}}$ have slightly lower reliability.

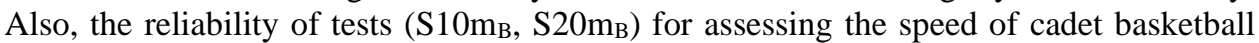
players when performed with a ball has been confirmed. These findings confirm the basic hypothesis of this research that tests for assessment of agility and speed, which are performed with and without a ball and which have the same movement pattern, are reliable for cadet basketball players.

The agility tests IL and Tt are more reliable when performed without a ball, while the $4 \times 5 \mathrm{~m}$ test is more reliable when performed with a ball. The findings confirm that speed tests which are performed with a ball have higher reliability than tests performed without a ball. All five tests which are performed with a ball are reliable for testing cadet basketball players.

There is a strong correlation between speed tests as well as between agility tests when performed with and without a ball. It can be concluded that these tests assess the same ability, regardless of whether they are performed with or without a ball. So, when the aim of testing the speed or agility of cadet basketball players is enough to choose one type of test, performed with or without a ball, but which have the same movement pattern. This fact emphasizes the importance of basic movement in understanding and testing speed and agility. Modifying the test, i.e. adding a ball to the basic pattern of movement, does not contribute to a better and more precise examination of the speed and agility of cadet basketball players. This indicates a high degree technique application in this age.

This study showed that the S20m test is not reliable when performed without a ball, while in all the other tests, reliability was determined regardless of whether they were performed with or without a ball. It is possible that this result is a consequence of a measurement error, because the reliability of this test has been confirmed in other studies. The reliability of the $\mathrm{S} 20 \mathrm{~m}_{\mathrm{NB}}$ test should be further investigated in future research. 


\section{CONCLUSION}

Speed and agility are significant motor abilities for a basketball player. It is necessary to know the level of these abilities of cadet basketball players in order to monitor, improve and organize the training process. The proposed agility and speed tests have been shown to be reliable for testing cadet basketball players.

The most reliable agility test when performed without a ball is the IL, while the Tt and $4 \times 5 \mathrm{~m}$ tests are slightly less reliable. When it comes to speed tests, when performed without a ball, the $\mathrm{S} 10 \mathrm{~m}$ test is more reliable, while the $\mathrm{S} 20 \mathrm{~m}$ test should be checked in future research. On the other hand, all speed and agility tests when performed with a ball are reliable for testing cadet basketball players.

This research confirmed that tests which basically have the same movement pattern assess the same ability. The strong correlation between tests performed with and without a ball justifies this thesis. Each test, observed separately, performed without a ball, had a strong relation with the test performed with a ball.

\section{REFERENCES}

Asadi, A. (2016). Relationship between jumping ability, agility and sprint performance of elite young basketball players: a field-test approach. Revista Brasileira de Cineantropometria et Desempenho Humano, 18(2), 177-186.

Bompa, T., \& Haff, G. G. (2009). Periodization: Theory and methodology of training, $5^{\text {th }}$ Edition. Champaign: Human Kinetics.

Borović, I., Rupčić, T., Matković, R., Garafolić, H., \& Dadić, M. (2016). Anthropological profile of U16 basketball players. Acta Kinesiologica, 10(1), 71-77.

Delextrat, A., Grosgeorge, B., \& Bieuzen, F. (2015). Determinants of performance in a new test of planned agility for young elite basketball players. International Journal of Sports Physiology and Performance, 10(2), 160-165.

Draper, J., \& Lancaster, M. (1985). The 505 test: A test for agility in the horizontal plane performance. Exercise and Sport Sciences Reviews, 31, 8-12.

Fulton, K.T. (1992). Basketball: Off-season strength training for basketball. Strength and Conditioning Journal, 14(1), 31-35.

Gabbett, T.J., Kelly, J.N., \& Sheppard, J.M. (2008). Speed, change of direction speed, and reactive agility of rugby league players. The Journal of Strength and Conditioning Research, 22(1), 174-181.

Gil, S.M., Yanci, J., Otero, M., Olasagasti, J., Badiola, A., Bidaurrazaga-Letona, I., et al. (2015). The functional classification and field test performance in wheelchair basketball players. Journal of Human Kinetics, 46(1), 219-230.

Hachana, Y., Chaabène, H., Nabli, M.A., Attia, A., Moualhi, J., Farhat, N., et al. (2013). Test-retest reliability, criterion-related validity, and minimal detectable change of the Illinois agility test in male team sport athletes. The Journal of Strength and Conditioning Research, 27(10), 2752-2759.

Hastad, D.N., \& Lacy, A.C. (1994). Measurement and evaluation in physical education and exercise science. Gorsuch Scarisbrick.

Hellström, J. (2008). The relation between physical tests, measures, and clubhead speed in elite golfers. International Journal of Sports Science and Coaching, 3(1), 85-92.

Jakovljević, S.T., Karalejić, M.S., Pajić, Z.B., Macura, M.M., \& Erculj, F.F. (2012). Speed and agility of 12-and 14-yearold elite male basketball players. The Journal of Strength and Conditioning Research, 26(9), 2453-2459.

Kukolj, M. (2006). Antropomotorika (Anthropomotorics). Belgrade: Faculty of Sport and Physical Education, University of Belgrade. In Serbian

Leone, M., Comtois, A.S., Tremblay, F., \& Léger, L. (2006). Specificity of running speed and agility in competitive junior tennis players. Medicine and Science in Tennis, 11, 10-11.

Little, T., \& Williams, A. (2003). Specificity of acceleration, maximum speed and agility in professional soccer players. London, UK: Routledge.

Mendez-Villanueva, A., Buchheit, M., Kuitunen, S., Douglas, A., Peltola, E., \& Bourdon, P. (2011). Age-related differences in acceleration, maximum running speed, and repeated-sprint performance in young soccer players. Journal of Sports Sciences, 29(5), 477-484. 
Milanović, Z., Sporiš, G., Trajković, N., James, N., \& Šamija, K. (2013). Effects of a 12 week saq training programme on agility with and without the ball among young soccer players. Journal of Sports Science and Medicine, 12(1), 97-103.

Nikolić, D., Berić, D., Kocić, M., \& Daskalovski, B. (2017). Complex training and sprint abilities of young basketball players. Facta Universitatis Series Physical Education and Sport, 15(1), 25-36.

Petrović, A. (2014). Interpretation of basic concepts in theories of human motor abilities. Physical Culture, 68(1), 13-28.

Sayers, M. (2000). Running techniques for field sports players. Sports Coach, 23(1), 26-27.

Scanlan, A.T., Wen, N., Kidcaff, A.P., Berkelmans, D.M., Tucker, P.S., \& Dalbo, V.J. (2016). Generic and sportspecific reactive agility tests assess different qualities in court-based team sport athletes. The Journal of Sports Medicine and Physical Fitness, 56(3), 206-213.

Sheppard, J.M., \& Young, W.B. (2006). Agility literature review: Classifications, training and testing. Journal of Sports Sciences, 24(9), 919-932.

Spasić, M., Krolo, A., Zenić, N., Delextrat, A., \& Sekulić, D. (2015). Reactive agility performance in handball; development and evaluation of a sport-specific measurement protocol. Journal of Sports Science and Medicine, 14(3), 501-506.

Yanci, J., Granados, C., Otero, M., Badiola, A., Olasagasti, J., Bidaurrazaga-Letona, I., et al. (2015). Sprint, agility, strength and endurance capacity in wheelchair basketball players. Biology of Sport, 32(1), 71-78.

Young, W., \& Farrow, D. (2006). A review of agility: Practical applications for strength and conditioning. Strength and Conditioning Journal, 28(5), 24-29.

Young, W., James, R., \& Montgomery, I. (2002). Is muscle power related to running speed with changes of direction? Journal of Sports Medicine and Physical Fitness, 42(3), 282-288.

\section{POUZDANOST TESTOVA ZA PROCENU BRZINE I AGILNOSTI KOŠARKAŠA KADETA}

Cilj ovog istraživanja je da se utvrdi da li su Illinois test (IL), T-test (Tt), 4x5m Šatl trčanje $(4 x 5 \mathrm{~m}), 20 \mathrm{~m}$ Sprint $(\mathrm{S} 20 \mathrm{~m}), 10 \mathrm{~m}$ Sprint $(\mathrm{S} 10 \mathrm{~m})$ pouzdani testovi u proceni brzine $i$ agilnosti košarkaša kadeta. Strategija ovog istraživanja podrazumevala je tradicionalni kvantitativni pristup istraživanju sa korelacionim studijskim dizajnom. Ukupan uzorak sastojalo se od 38 muških ispitanika. Srednja starost ispitanika bila je $-A G E=16.03$ godina, telesna visina- $B H=183.5 \mathrm{~cm}$; telesna masa-BM=74.1 kg; Indeks telesne mase-BMI=22.08 kg/m². Najpouzdaniji test agilnosti pri izvođenju bez lopte je ILNB, dok su manje pouzdani $T_{N B} i 4 x 5 m_{N B}$, oba bez lopte. Pouzdan test koji se izvodi bez lopte za procenu brzine kadeta košarkaša je S10mNB. Sa druge strane, svi testovi brzine $i$ agilnosti kada se izvode sa loptom pouzdani su za testiranje košarkaša kadeta. Predloženi testovi brzine i agilnosti pokazali su se pouzdanima za košarkaše kadete.

Ključne reči: Illinois test, T-test, $4 x 5 m$ šatl trčanje, sprint 